J. Akademika Kim. 4(4): 161-167, November 2015

ISSN 2302-6030 (p), 2477-5185 (e)

\title{
PENGARUH PENERAPAN MODEL PEMBELAJARAN KOOPERATIF TIPE JIGSAW PADA MATERI KESETIMBANGAN KIMIA TERHADAP HASIL BELAJAR SISWA KELAS XI MIA SMA NEGERI 2 PALU
}

\section{Influence Application of a Cooperative Learning Model Jigsaw in Chemical Equilibrium Topic on Learning Outcomes of Students in Class XI MIA SMA Negeri 2 Palu}

\author{
* Maria Sisilia, Jamaluddin Sakung, dan Irwan Said \\ Pendidikan Kimia/FKIP - Universitas Tadulako, Palu - Indonesia 94118 \\ Received 01 September 2015, Revised 01 October 2015, Accepted 02 November 2015
}

\begin{abstract}
The aim of this study is to determine the learning outcomes of students in the class which is treated with the cooperative learning model Jigsaw whether it is better than the untreated class on chemical equilibrium topic. This study is a quasi-experimental research design with Non Randomized PretestPosttest control group design. The population in this study is 245 students of class XI MIA with academic year 2014/2015, from 8 classes. The sample in this study class XI MIA $5(n=32)$ as an experimental class while class XI MIA $6(n=32)$ as a control class. The analysis of data obtained in the experimental class, $X_{1} 1$ valueis 79.66 with a standard deviation $=9.41$. In the control class, $X_{2}$ valueis 70.03 with a standard deviation $=11.13$. The result of hypothesisis found that $t_{\text {calculated }}>t_{\text {table }}(5.53>1.67)$ with a significance level $(\alpha=0.05)$ and degrees of freedom $=62$. This shows that HO is rejected and H1 is accepted. Therefore, it can be concluded that student learning outcomes in class which is treated using the cooperative learning model Jigsaw is better than the untreated class on chemical equilibrium topic.
\end{abstract}

Keywords: Cooperative learning. Jigsaw model, Chemical Equilibrium, Learning Outcomes

\section{Pendahuluan}

Berdasarkan teori belajar konstruktivisme, belajar dapat dilihat sebagai suatu proses yang aktif. Siswa diberi kesempatan untuk membangun pengetahuan bukan diberi pengetahuan melalui pengajaran, sehingga siswa membangun pengetahuannya dari pengalaman belajarnya sendiri (Wijaya, 2012).

Guru sering menghadapi siswa yang mengalami gangguan perhatian dalam proses pembelajaran di kelas sehingga siswa kurang memusatkan perhatiannya dalam mengikuti pembelajaran. Siswa tersebut kurang dapat mengetahui dan memahami materi pelajaran yang diajarkan oleh guru sehingga memperoleh hasil belajar yang rendah. Gejala yang dialami siswa di kelas seperti yang tercantum di atas haruslah diketahui dan dipahami oleh guru

*Correspondence:

Maria Sisilia

Program Studi Pendidikan Kimia, Fakultas Keguruan dan

IImu Pendidikan, Universitas Tadulako

email: mariasisilia17@gmail.com

Published by Universitas Tadulako 2015 sebagai pengajar dan pendidik untuk mencegah dan mengatasi kesulitan belajar (Yulaikah, 2013).

Perubahan dalam hasil belajar siswa, dapat diperoleh dengan menggunakan strategi suatu model pembelajaran yang dapat meningkatkan hasil belajar siswa. Salah satu model pembelajaran yang sering diterapkan di berbagai jenjang pendidikan adalah model pembelajaran kooperatif (cooperative learning). Di dalam pembelajaran kooperatif siswa dilatih untuk mampu berfikir kritis dan toleran terhadap siswa lainnya (Kariasa, 2013).

Berdasarkan hasil observasi dan wawancara dengan salah seorang guru kimia di SMA Negeri 2 Palu, mengungkapkan bahwa kurikulum 2013 telah diterapkan di sekolah ini. Nilai rata-rata hasil belajar siswa kelas XI MIA SMA Negeri 2 Palu tahun pelajaran 2013/2014 yaitu 65,79 . Hal ini disebabkan karena model pembelajaran yang biasa digunakan masih bersifat konvensional. Disamping itu, proses pembelajaran sebagian besar masih berpusat 
pada guru sebagai sumber utama pengetahuan, sehingga siswa kurang aktif dalam pembelajaran.

Kesetimbangan kimia merupakan salah satu meteri pelajaran kimia, siswa mengalami kesulitan dalam mempelajari materi ini (Kariasa, 2013). Oleh karena itu perlu dicari alternatif model pembelajaran yang dapat lebih meningkatkan minat belajar pada siswa. Pembelajaran dengan menerapkan model pembelajaran kooperatif tipe Jigsaw adalah salah satu upaya yang baik yang dilakukan dalam proses pembelajaran kimia khususnya materi kesetimbangan kimia. Model pembelajaran kooperatif tipe Jigsaw dapat menciptakan suasana yang menyenangkan dalam proses belajar dan membangkitkan motivasi siswa dalam belajar. Pada saat dilakukan pembelajaran dapat menarik perhatian belajar siswa. Hal tersebut sesuai dengan penelitian yang dilakukan oleh Resor (2008) yang menemukan beberapa komentar dari siswa yang diajar dengan model Jigsaw. Sebagian besar komentar siswa adalah model pembelajaran Jigsaw membuat pelajaran menjadi lebih menarik dan meningkatkan kemampuan berfikir secara mendalam dan kemampuan melakukan analisis secara kritis. Seorang siswa mengatakan model pembelajaran Jigsaw menyenangkan (fun).

Pembelajaran kooperatif tipe Jigsaw merupakan salah satu tipe strategi pembelajaran kooperatif dan fleksibel. Dalam pembelajaran tipe Jigsaw, siswa dibagi menjadi kelompokkelompok yang anggotanya mempunyai karakteristik heterogen. Masing-masing siswa bertanggung jawab untuk mempelajari topik yang di tugaskan dan mengajarkan pada anggota kelompoknya, sehingga mereka dapat saling berinteraksi dan saling bantu (Hertiavi, dkk., 2010).

\section{Metode}

Penelitian ini merupakan quasi experiment yang dilaksanakan di SMA Negeri 2 Palu. Desain penelitian yang digunakan dalam penelitian adalah Non Randomized PretestPosttest Control Group Design (Creswell, 1994).

Populasi dari penelitian ini adalah seluruh siswa kelas XI MIA SMA Negeri 2 Palu dengan jumlah populasi 245 orang yang terdiri dari kelas XI MIA 1, XI MIA 2, XI MIA 3, XI MIA 4, XI MIA 5, XI MIA 6, XI MIA 7 dan XI MIA 8 yang terdaftar pada tahun ajaran 2014/2015. Sampel pada penelitian ini adalah siswa kelas XI MIA 5 yang berjumlah 32 orang sebagai kelas eksperimen dan kelas XI MIA 6 yang berjumlah 32 orang sebagai kelas kontrol. Pemilihan kedua kelas tersebut dilakukan berdasarkan teknik purposive sampling. Variabel bebas pada penelitian ini adalah penerapan model pembelajaran kooperatif tipe Jigsaw di kelas XI MIA 5 SMA Negeri 2 Palu. Variabel terikat pada penelitian ini adalah hasil belajar siswa pada materi Kesetimbangan Kimia di kelas XI MIA 5 SMA Negeri 2 Palu.

Instrumen penelitian ini adalah tes awal sebanyak 20 nomor dalam bentuk pilihan ganda, angket, penilaian afektif, penilaian psikomotorik dan tes hasil belajar kesetimbangan kimia yang dibuat dalam bentuk pilihan ganda yang sudah di uji validitasnya. Soal digunakan untuk mengukur hasil belajar kognitif sebelum dan sesudah pembelajaran. Pengolahan data hasil penelitian dilakukan melalui uji prasyarat dan pengujian hipotesis.

Pengujian hipotesis dilakukan untuk melihat apakah hipotesis yang telah dirumuskan didukung oleh data yang telah dikumpulkan. Dalam hal ini pasangan hipotesis nol tandingannya yang akan diuji. Secara matematisnya dapat dinyatakan sebagai berikut:

$\mathrm{H}_{0}$ : Hasil belajar dengan model pembelajaran kooperatif tipe Jigsaw kurang dari atau sama dengan pembelajaran diskusi kelompok.

$\mathrm{H}_{1}$ : Hasil belajar dengan model pembelajaran kooperatif tipe Jigsaw lebih baik dari pada pembelajaran diskusi kelompok.

Kriteria pengujiannya adalah terima $\mathrm{H}_{0}$ jika $t_{\text {hitung }} \leq t_{(1-\alpha)}$ dimana $t_{(1-\alpha)}$ diperoleh dari daftar distribusi t dengan $\mathrm{dk}=\left(\mathrm{n}_{1}+\mathrm{n}_{2}-2\right)$ dan peluang (1- $\alpha$ ) dengan taraf signifikan 0,05. Untuk harga t lainnya $\mathrm{H}_{0}$ ditolak. Berdasarkan data yang diperoleh, harga $\mathrm{t}_{(0,95)}$ dengan $\mathrm{dk}=62$ dari daftar distribusi adalah 1,67. Dimana pada kriteria pengujiannya adalah: terima $\mathrm{H}_{0}$ jika $\mathrm{t}_{\text {hitung }} \leq \mathrm{t}_{\text {tabel }}(1-\alpha),\left(\mathrm{n}_{1}+\mathrm{n}_{2}-2\right)$ dan tolak $\mathrm{H}_{0}$ jika $t_{\text {hitung }}>t_{\text {tabel }}(1-\alpha),\left(n_{1}+n_{2}-2\right)$ (Sudjana, 2005).

\section{Hasil dan Pembahasan}

Instrumen yang digunakan untuk mengukur hasil belajar siswa kelas XI MIA SMA Negeri 2 Palu berjumlah 20 butir soal dalam bentuk pilihan ganda. Instrumen tersebut telah diuji validitas, reliabilitas, daya beda, dan tingkat kesukarannya dari 40 butir soal yang tersedia.

Berdasarkan penelitian yang dilakukan maka diperoleh hasil pengujian normalitas, homogenitas dan hipotesis penelitian dari data tes akhir pada kelas eksperimen dan kelas kontrol. 


\section{Pengujian Normalitas}

Pengujian normalitas diperoleh data berdistribusi normal atau tidak, sehingga dilakukan pengujian dengan menggunakan uji Chi-kuadrat (X') (Sudjana, 2005). Dalam pengujian normalitas data dikatakan normal jika $\mathrm{X}_{\text {hitung }}^{2}<\mathrm{X}_{\text {tabel. }}^{2}$. Berdasarkan hasil yang diperoleh pada kelas eksperimen diperoleh hasil $\mathrm{X}_{\text {hitung }}^{2}=5,71$, dan kelas kontrol $\mathrm{X}_{\text {hitung }}^{2}=7,49$, sedangkan nilai pada $X_{\text {tabel }}^{2}=7,81$. Sehingga dapat disimpulkan bahwa kedua sampel tersebut berdistribusi normal.

Tabel 1. Hasil Pengujian Normalitas, Homogenitas dan Hipotesis

\begin{tabular}{|l|c|c|c|c|c|c|}
\hline \multirow{2}{*}{ Kelas } & \multicolumn{2}{|c|}{ Uji Normalitas } & \multicolumn{2}{c|}{ Uji Homogenitas } & \multicolumn{2}{c|}{ Uji Hipotesis } \\
\cline { 2 - 7 } & $\chi_{\text {hitung }}$ & $\chi_{\text {tabel }}$ & $\mathrm{F}_{\text {hitung }}$ & $\mathrm{F}_{\text {tabel }}$ & $\mathrm{t}_{\text {hitung }}$ & $\mathrm{t}_{\text {tabel }}$ \\
\hline Eksperimen & 5,71 & 7,81 & 1,39 & 2,38 & 15,53 & 1,67 \\
\hline Kontrol & 7,49 & 7,81 & 1,39 & 2,38 & 15,53 & 1,67 \\
\hline
\end{tabular}

\section{Pengujian Homogenitas}

Pengujian homogenitas ini merupakan salah satu syarat dalam menyatakan perbedaan kedua kelas, dimana sampel harus homogen dengan melakukan uji F (kesamaan dua varians) (Sudjana, 2005) Sehingga diperoleh varians terbesar $=124,03$ sedangkan varians terkecil $=88,68$. Maka diperoleh nilai $\mathrm{F}_{\text {hitung }}=1,39$ dan $\mathrm{F}_{\text {tabel }}=2,38$ dengan $\alpha=0,05$ dan $\mathrm{dk}=$ $(31,31)$. Maka data tersebut memenuhi kriteria homogen yaitu $\mathrm{F}_{\text {hitung }}<\mathrm{F}_{\text {tabel }}$ yaitu $1,39<2,38$.

\section{Pengujian Hipotesis}

Pengujian ini dilakukan untuk melihat apakah hipotesis yang telah dirumuskan didukung oleh data yang telah dikumpulkan. Berdasarkan penelitian diperoleh $t_{\text {hitung }}=15,53$ dan $t_{\text {tabel }}=1,67$, sehingga jelas $t_{\text {hitung }}$ berada di daerah penolakan $\mathrm{H}_{0}$ dimana $\mathrm{t}_{\text {hitung }}>\mathrm{t}_{\text {tabel }}$ yaitu $15,53>1,67$, maka jelas berada pada daerah penolakan $\mathrm{H}_{0}$ jadi $\mathrm{H}_{0}$ ditolak dan $\mathrm{H}_{1}$ diterima, maka dapat disimpulkan bahwa hasil belajar siswa pada kelas yang diberi perlakuan dengan menggunakan model pembelajaran kooperatif tipe Jigsaw lebih baik dibanding kelas yang tidak diberi perlakuan pada materi kesetimbangan kimia.

Dalam pelaksanaan penelitian ini kelompok eksperimen dan kelompok kontrol menggunakan jumlah waktu pembelajaran yang sama, yaitu 8 jam pelajaran. Selain jumlah waktu pembelajaran yang sama, pokok materi yang disampaikan pada kelompok eksperimen dan kelompok kontrol juga sama yaitu kesetimbangan kimia dengan urutan penyampaian materi yang sama pula. Jadi, perlakuan yang berbeda hanya pada metode pembelajaran yang digunakan. Pada kelompok eksperimen dengan menggunakan model pembelajaran kooperatif tipe jigsaw sedangkan pada kelompok kontrol menggunakan metode diskusi kelompok.

Sebelum melaksanakan pembelajaran dilakukan tes awal pembelajaran (pretest) dalam bentuk pilihan ganda sebanyak 20 butir soal, yang bertujuan untuk mengetahui pengetahuan awal siswa tentang materi kesetimbangan kimia dan selanjutnya akan dibandingkan dengan hasil tes akhir (postest) dalam bentuk pilihan ganda dengan jumlah soal sebanyak 20 butir pada akhir pembelajaran yang bertujuan untuk mengetahui hasil belajar siswa yang di beri perlakuan dan tidak. Soal-soal yang digunakan dalam pretest dan postest ini telah diuji cobakan di kelas XII SMA Negeri 2 Palu dan telah terbukti memenuhi syarat untuk digunakan sebagai tes standar. Sehingga untuk reliabilitas dan validitasnya tidak diragukan lagi.

Penelitian ini, untuk kelas eksperimen langkah awal yang dilakukan oleh peneliti pada kegiatan inti adalah menjelaskan mengenai teknik pelaksanaan model pembelajaran kooperatif tipe Jigsaw. Selanjutnya peneliti meminta siswa untuk membentuk kelompok (kelompok asal) setiap kelompok terdiri dari 4 orang. peneliti membagikan kepada masingmasing siswa LKS lalu menugaskan setiap siswa untuk mempelajari satu bagian materi dalam LKS tersebut. Setelah siswa mempelajari materi dalam LKS peniliti meminta siswa untuk membentuk kelompok-kelompok ahli, yang anggotanya adalah siswa dari masing-masing kelompok asal. Mereka bergabung menjadi satu kelompok (ahli) untuk mempelajari satu bagian materi yang sama. Siswa diberi kesempatan untuk mendiskusikan tugas yang diberikan tersebut. Setelah siswa selesai mendiskusikannya peneliti meminta masing-masing siswa untuk kembali kekelompok asal mereka, kemudian masing-masing siswa mempresentasikan materi bagiannya dikelompok asal. Selanjutnya mereka diajak untuk mendiskusikan kembali hasil diskusi mereka. Pada tahap ini pengajar memberikan penguatan terhadap siswa dan menilai siswa secara kelompok.

Penelitian untuk kelas kontrol, pembelajaran berlangsung menggunakan metode pembelajaran diskusi kelompok, 
pengajar hanya mengajar seperti biasa. Kegiatan pembelajaran dimulai dari uraian untuk memperjelas bahan ajar yang disertai dengan contoh-contoh, siswa mencatat, bertanya, kemudian guru menjawab dan diakhiri dengan latihan sebagai umpan balik. Menggunakan metode tersebut, keaktifan siswa sangat kurang. Siswa tidak terdorong untuk mencari tetapi hanya menerima apa yang diberikan, dengan metode diskusi kelompok minat dan kreatifitas siswa tidak terdorong untuk berkembang.

Berdasarkan hasil penelitian dan analisis data diperoleh bahwa hasil belajar siswa pada kelas yang diberi perlakuan dengan menggunakan model pembelajaran kooperatif tipe Jigsaw lebih baik dibanding kelas yang tidak diberi perlakuan pada materi kesetimbangan kimia. Hal ini dapat dilihat dari nilai rata-rata yang diperoleh siswa kelas eksperimen $=79,66$ dengan simpangan baku $=9,41$ dan nilai rata-rata siswa kelas kontrol $=70,03$ dengan simpangan baku $=11,39$.

Berdasarkan hasil penelitian yang telah diperoleh dari kedua kelas untuk analisis statistik deskriptif dengan menggunakan uji $\mathrm{N}$-gain untuk menentukan hubungan nilai pretest dan posttest baik kelas eksperimen maupun kelas control (Hake, 1998). Hasil yang diperoleh disajikan dalam Grafik 1

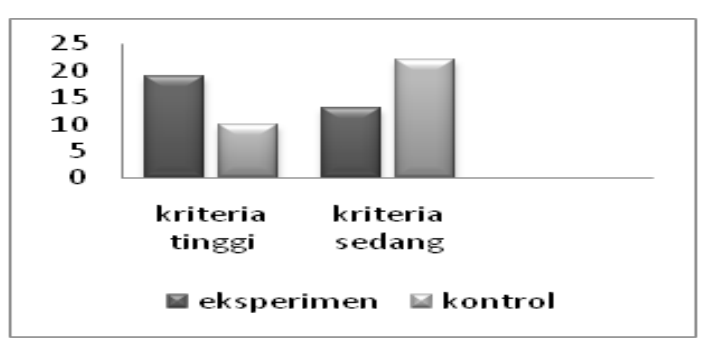

Grafik 1. Nilai N-gain kelas kontrol dan kelas eksperimen

Nilai N-gain kelas kontrol dan kelas eksperimen

Berdasarkan hal tersebutbahwapembelajaran dengan menggunakan model pembelajaran kooperatif tipe jigsaw memberikan hasil belajar yang lebih baik. Hal ini dikarenakan model pembelajaran kooperatif tipe jigsaw merupakan model pembelajaran yang sangat menarik untuk diterapkan kepada siswa.

Pembelajaran kooperatif merupakan sebuah pengembangan teknik belajar bersama. Dalam hal ini belajar bersama berarti melakukan sesuatu secara bersama, saling membantu dan bekerja sebagai sebuah tim (kelompok). Jadi pembelajaran kooperatif berarti belajar bersama, saling membantu dalam pembelajaran agar setiap anggota kelompok dapat mencapai tujuan atau menyelesaikan tugas yang diberikan dengan baik (Suwarno, 2007). Dengan belajar secara kooperatif, pemahaman siswa tentang tujuan berkelompok akan membantu dalam mendukung pembelajaran satu sama lain yang pada akhirnya akan memotivasi mereka untuk saling memberikan informasi (Gillies \& Boyle, 2010).

Siswa bekerja dalam kelompok yang masing冈masing terdiri dari empat siswa, laki laki dan perempuan dengan kemampuan yang heterogin di dalam kelompok. Hasil penelitian menunjukkan bahwa siswa yang belajar dalam kelompok terstruktur lebih kooperatif dan lebih banyak saling memberikan bantuan antara yang satu dengan yang lain ketika belajar bersama dalam kelompok, dibandingkan dengan siswa dalam kelompok yang tidak terstruktur. Selain itu, juga ditemukan bahwa siswa yang belajar dalam kelompok terstruktur memiliki persepsi yang kuat bahwa belajar dalam kelompok kecil sangat menyenangkan dan memungkinkan mereka memperoleh kesempatan untuk belajar bersama secara berkualitas (Gillies, 2003).

Manfaat model dari sudut pandang siswa, mereka menyatakan bahwa sepanjang proses belajar tidak pernah merasa bosan, komunikasi di kelas terpelihara dengan baik, dan belajar materi pelajaran dengan perasaan yang gembira. Hal ini merupakan aspek-aspek yang penting yang menunjukkan fakta akan adanya sisi positif dari penerapan teknik jigsaw (Arjanggi \& Setiowati, 2013).

Jigsaw adalah salah satu tipe pembelajaran kooperatif. Dalam pembelajaran kooperatif tipe Jigsaw, siswa ditempatkan dalam kelompok belajar yang anggotanya mempunyai kemampuan berbeda-beda baik kemampuan belajar tinggi, sedang, maupun rendah (bersifat heterogen). Dalam metode ini, setiap siswa dalam suatu kelompok diberikan informasi yang hanya menekankan pada suatu bagian pelajaran. Selanjutnya, tiap-tiap siswa akan menjelaskan kepada kelompoknya informasi yang diperoleh sehingga dalam metode ini tiaptiap siswa akan berusaha memahami bagian informasi yang didapatkan (Kariasa, 2013).

Pembelajaran kooperatif Jigsaw setiap anggota kelompok dituntut untuk belajar menjadi ahli (expert) dalam sub topik bagiannya dan mampu mengajarkannya sub topik tersebut kepada kelompok asalnya. Dengan demikian setiap siswa termotivasi untuk secara aktif mengkontruksi konsep atau pengetahuannya, karena ia tidak. hanya bertanggung jawab 
terhadap keberbasilan belajamya sendiri, tetapi juga keberhasilan belajar kelompoknya (Supini \& Manurung, 2010).

Pembelajaran dengan menerapkan model pembelajaran kooperatif tipe jigsaw adalah salah satu upaya yang baik yang dilakukan dalam proses pembelajaran kimia khususnya materi kesetimbangan kimia. Setelah dilakukan pembuktian antara dua variabel dengan uji-t dapat diketahui bahwa pengujian hipotesis penelitian ini ada perbedaan yang signifikan antara yang mendapat perlakuan model pembelajaran kooperatif tipe jigsaw dengan pembelajaran yang menggunakan metode pembelajaran diskusi kelompok, dimana hasil belajar siswa pada kelas yang diberi perlakuan dengan menggunakan model pembelajaran kooperatif tipe Jigsaw lebih baik dibanding kelas yang tidak diberi perlakuan pada materi kesetimbangan kimia. Perbedaan dari hasil belajar siswa pada kelas eksperimen dan kelas kontrol ini dapat terjadi karena model pembelajaran kooperatif tipe jigsaw dapat menciptakan suasana yang menyenangkan dalam proses belajar dan membangkitkan motivasi siswa dalam belajar. Pada saat dilakukan pembelajaran dapat menarik perhatian belajar siswa.

Beberapa komentar yang ditemukan dari siswa yang diajar dengan metode jigsaw, sebagian besar komentar mereka adalah bahwa metode pembelajaran jigsaw membuat pelajaran menjadi lebih menarik dan meningkatkan kemampuan berfikir secara mendalam dan kemampuan melakukan analisis secara kritis. Seorang siswa mengatakan metode jigsaw menyenangkan (fun) (Resor, 2008). Belajar kooperatif selain memberikan kontribusi secara positif terhadap prestasi akademik, juga meningkatkan keterampilan sosial dan selfesteem siswa (Manning \& Lucking, 1991).

Penelitian tentang pengaruh metode jigsaw terhadap kinerja akademik dan non $\mathbb{Z}$ akademik pada siswa sekolah menengah yang mengikuti mata pelajaran Ilmu Alam. Satu dari dua kelompok siswa yang penempatannya dilakukan secara random, diajar dengan metode jigsaw (kelompok eksperimen) dan kelompok lainnya diajar dengan metode tradisional (kelompok kontrol). Hasilnya menunjukkan bahwa kelompok eksperimen memiliki kinerja akademik yang lebih tinggi, berkurang prasangka dan prejudicenya, serta meningkat hubungan sosialnya dibandingkan dengan kelompok kontrol (Cang \& Mao, 1999).

Teknik jigsaw merupakan cara yang paling efektif dalam meningkatkan partisipasi siswa dalam belajar sehingga prestasi siswa dalam belajar meningkat (Mengduo \&Xiaoling, 2010). Dan teknik jigsaw juga dapat meningkatkan prestasi belajar jika dibandingkan dengan model konvensional (Ahmad \& Jazuli, 2009). Sintaks kooperatif Jigsaw membantu peserta didik belajar saling membantu, berdiskusi, dan berargumentasi untuk memahami, mengerti dan mengetahui suatu topik secara bersama (Palennari, 2011).

Proses pembelajaran di kelas dapat berhasil secara maksimal, jika hubungan guru dengan peserta didik, dan hubungan peserta didik dengan peserta didikyang lain terjadi secara baik. Maka suasana dalam kegiatan pembelajaran menjadi efektif dan menyenangkan sehingga siswa dapat menguasai materi pelajaran dengan baik (Yulaikah, 2013).

Aplikasi model pembelajaran kooperatif tipe jigsaw tidak hanya menginginkan siswa untuk belajar ketrampilan dan isi akademik, tetapi juga melatih siswa dalam mencapai tujuan-tujuan hubungan sosial dan manusia, yang pada akhirnya berpengaruh terhadap prestasi akademik siswa. Pada perkembangan selanjutnya pembelajaran kooperatif tipe jigsaw selalu mengadakan diskusi kelompok ahli tiap awal sebelum diskusi kelompok asal. Pada akhirnya setiap siswa dalam kelas dapat mencapai hasil belajar yang maksimal dan sejajar. Dalam proses diskusi dan kerja kelompok guru hanya berfungsi sebagai fasilitator, konsultan dan manager yang mengkoordinir proses pembelajaran. Suasana belajar dan interaksi yang santai antara siswa dan guru maupun antar siswa membuat proses berfikir siswa lebih optimal dan siswa mengkontruksi sendiri ilmu yang dipelajarinya menjadi pengetahuan yang akan bermakna dan tersimpan dalam ingatannya untuk waktu yang lama (Sugianto, dkk., 2014).

\section{Kesimpulan}

Hasil belajar siswa pada kelas yang diberi perlakuan dengan menggunakan model pembelajaran kooperatif tipe Jigsaw lebih baik dibandingkan dengan kelas yang tidak diberi perlakuan pada materi kesetimbangan kimia. Hal ini dapat dilihat dari skor rata-rata postest dari masing-masing kelas, yaitu pada kelas eksperimen $=79,66$, dan kelas kontrol $=70,03$. Hal tersebut diperkuat oleh hasil analisis data statistik dengan nilai $t_{\text {hitung }}>t_{\text {tabel }}$ yaitu $15,53>$ 1,67 pada taraf signifikan $\alpha=0,05$ dan derajat kebebasan, $\mathrm{dk}=62$ sehingga hipotesis dapat 
diterima pada taraf kepercayaan $95 \%$.

\section{Ucapan Terima Kasih}

Penulis mengucapkan terima kasih kepada Badrah Lahay kepala sekolah SMA Negeri 2 Palu dan Satria guru mata pelajaran kimia SMA Negeri 2 Palu yang telah banyak membantu selama penelitian.

\section{Referensi}

Ahmad, \& Jazuli, A. (2009). Jigsaw type of cooperative learning as a means of improving high school students mathematical communication ability. International Journal For Educational Studies, 1(2), $207-$ 218.

Arjanggi, R., \& Setiowati, E. A. (2013). Meningkatkan belajar berdasar regulasi diri melalui pembelajaran kooperatif tipe jigsaw. Jurnal Makara Seri Sosial Humaniora, 17(1), 55-63.

Cang, C. Y., \& Mao, S. L. (1999). The effects on student's cognitive achievement when using the cooperative learning method in earth science classrooms. School Science And Mathematics, 99(7), 374-379.

Creswell, J. W. (1994). Research design qualitative \& quantitative approaches. U.S.A: SAGE Publication.

Gillies, R. M. (2003). The behaviors, interactions, and perceptions of junior high school students during small-group learning. Journal of Educational Psychology, 95(1), 137-147.

Gillies, R. M., \& Boyle, M. (2010). Teachers' reflections on cooperative learning: issues of implementation. Teaching And Teacher Education, 26(3), 933-940.

Hake, R. R. (1998). Interactive-engagement versus traditional methods: A six-thousandstudent survey of mechanics test data for introductory physics courses. American Journal of Physics, 66(1), 64-74.

Hertiavi, M. A., Langlang, H., \& Khanafiyah, S. (2010). Penerapan model pembelajaran kooperatif tipe jigsaw untuk peningkatan kemampuan pemecahan masalah siswa SMP. Jurnal Pendidikan Fisika Indonesia, 6(1), 53-57.

Kariasa, I. W. (2013). Penerapan model pembelajaran kooperatif tipe jigsaw untuk meningkatkan hasil belajar kimia di SMAN 1 Nusa Penida. Jurnal Ilmiah Disdikpora Kabupaten Klungkung, 1(1), 1-11.

Manning, M. I., \& Lucking, R. (1991). The what, why and how of cooperative learning. Journal Social Studies, 82(5), 67-75.

Mengduo, Q., \& Xiaoling, J. (2010). Jigsaw strategy as a cooperative learning technique: Focusing on the language learners. Chinese Journal of Applied Linguistics (bimonthly), 33(4), 113-125.

Palennari, M. (2011). Potensi strategi integrasi PBL dengan pembelajaran kooperatif jigsaw dalam meningkatkan pemahaman konsep mahasiswa. Jurnal Ilmiah Pendidikan Biologi, 3(2), 26-33.

Resor, C. (2008). Encouraging students to read the text: the jigsaw method theaching history. A Journal of Methods, 28(5), 111113.

Sudjana. (2005). Metoda statistika. Bandung: Tarsito.

Sugianto, Armanto, D., \& Harahap, M. B. (2014). Perbedaan penerapan model pembelajaran kooperatif tipe jigsaw dan stad ditinjau dari kemampuan penalaran dan komunikasi matematis siswa SMA. Jurnal Didaktik Matematika, 1(1), 114-128. 
Supini, \& Manurung, B. (2010). Pengaruh pembelajaran koopera tif tipe jigsaw dan teknik peta pikiran terhadap hasil belajar sistem regulasi di SMAN 1 Lubukpakam. Jurnal Pendidikan Biologi, 1(2), 69-145.

Suwarno. (2007). Meningkatkan prestasi belajar matematika siswa melalui pembelajaran kooperatif jigsaw (ptk pada siswa kelas VII E SMP Negeri 4 Sukoharjo). Jurnal Pendidikan, 16(2), 137-150.
Wijaya, M. (2012). Pengembangan model pembelajaran e-learning berbasis web dengan prinsip e-pedagogy dalam meningkatkan hasil belajar. Jurnal Pendidikan Penabur, 11(19), 20-37.

Yulaikah, M. (2013). Penerapan jigsaw untuk meningkatkan hasil belajar siswa sekolah dasar. Jurnal Dinas Pendidikan Kota Surabaya, 6(4), 1-8. 